\title{
Role of Media in Provoking Cigarette Smoking among Adolescents in Urban Nepal
}

\author{
Sushma Dahal1 ${ }^{*}$, Sabeena Maharjan², Raj Kumar Subedi1 ${ }^{1}$ Juna Maharjan ${ }^{3}$ \\ ${ }^{1}$ Department of Public Health, Central Institute of Science and Technology (CIST College), Kathmandu, Nepal \\ ${ }^{2}$ Department of Social Science, Tribhuwan University, Kathmandu, Nepal \\ ${ }^{3}$ Lumanti Support Group for Shelter, Kathmandu, Nepal \\ Email: ${ }^{*}$ sushdahal@gmail.com
}

Received 18 December 2014; accepted 3 January 2015; published 15 January 2015

Copyright (C) 2015 by authors and Scientific Research Publishing Inc.

This work is licensed under the Creative Commons Attribution International License (CC BY).

http://creativecommons.org/licenses/by/4.0/

c) (i) Open Access

\begin{abstract}
At current era of globalization, media is the double edged sword that is important both for health education as well as the stimulation of unhealthy behaviour. In Nepal, though there is ban on most forms of advertising, it is not clear about placement of tobacco advertisement in TV, films and other forms of media. Studies about cigarette smoking and its association with media are inadequate in Nepal. The objective of this study was to explore the role of media in cigarette smoking habit of adolescents in Nepal. A cross-sectional study was conducted among 394 adolescent students by using questionnaire method in 3 randomly selected colleges of Kathmandu district, Nepal. Data were analysed by using bivariate and multinomial logistic regression analysis. Statistically significant relationship at $\mathbf{9 5 \%}$ CI was found between cigarette smoking status and media related variables like: seeing cigarette advertisement, reading fashion magazine, attending musical program sponsored by cigarette companies, watching movies in cinema hall, liking heavy metal/hard rock music, television watching time and desire to smoke if favourite artist smokes. Multinomial logistic regression showed that those with high receptivity to cigarette advertisement were likely to be current smokers (OR = 71.416, CI: 8.796 - 579.823) and ever smokers (OR = 9.582, CI: 2.201 41.714) compared to never smokers. About $79 \%$ of respondents agreed that media teaches different ways of smoking to its audiences. Different forms of media including cinema, music, magazines, television, games and music sponsorship are found to be important predictors for smoking status of college students in urban Nepal. Thus smoking prevention activities should consider role of media in smoking provocation among adolescents.
\end{abstract}

\section{Keywords}

Adolescents, Cigarette Advertisement, Media, Provocation, Smoking

*Corresponding author. 


\section{Introduction}

According to WHO, tobacco is the single largest preventable risk factor for various diseases including premature deaths and disability around the world. It kills nearly six million people each year of which more than five million are users and ex-users and more than 600,000 are nonsmokers exposed to second-hand smoke [1]. Tobacco products are the only legally available products that can kill up to one half of their regular users if consumed as recommended by the manufacturer [2]. In Nepal, tobacco use is more common among men (52\%) than women (13\%). Of the men using tobacco, 30\% smoke cigarette while 38\% consumed other forms of tobacco. Among women, 9 percent smoke cigarette and 6 percent consumed other forms of tobacco [3]. Prevalence of smoking among adult females in Nepal is one of the highest in the WHO South-East Asia Region [4].

The population of Nepal has increased to $26,621,000$ with the annual growth rate of $1.4 \%$ [5]. As a consequence of a high growth rate, majority of population of the country is fairly young. There are several factors that increase the risk of youth smoking. Availability, accessibility and affordability, pressure from peer or siblings; having a lower self-image than peers, perceiving that tobacco use is normal or "cool" and parental smoking are important risk factors associated with youth smoking [6] [7]. Advertising and promotional activities are considered to influence key risk factors for tobacco use among adolescents [8].

The U.S. Food and Drug Administration's 1995 review of available tobacco industry documents highlighted that cigarette manufacturers know that young people are vital for their market, so they need to develop advertising and other promotional activities that appeal to young people [9]. Tobacco marketing capitalizes upon issues that are of great importance to adolescents because of which it is likely that adolescents are influenced to smoke cigarettes [10] and the presence of tobacco use in young is more serious problem as they may be exposed for longer periods.

Studies reflect that media can play role in both increasing and decreasing the exposure of tobacco among the different at risk group. On one hand, media can shape and reflect social values about smoking, can provide new information about smoking directly to audiences, can act as the source of observational learning by providing models which teenagers may seek to emulate; exposure to media messages about smoking also provides direct reinforcement for smoking or not smoking. On the other hand, the media promote interpersonal discussion about smoking, can influence "intervening" behaviors that may make teenage smoking less likely; and antismoking media messages can also set the agenda for other change at the community, state or national level [11].

The Tobacco Product Control and Regulatory Bill, 2010 was approved by Nepal's legislature on April, 2011. Major features of this law include a complete ban on smoking in public places, workplaces and public transportation; cover $75 \%$ of cigarette and other tobacco product packaging space with pictorial health warning; health tax on tobacco product and total ban on tobacco advertisement, promotion and sponsorship in any form [12]. Though there is a ban on most forms of tobacco advertising, it is unclear whether some types of promotional practices are prohibited as the law does not provide a definition of "tobacco advertising and promotion [13]. It is unclear whether paid placement of tobacco products in TV, film and other media is encompassed by the ban [14].

In Nepal, studies about tobacco use, its correlates and media role among college students in Nepal are inadequate. Moreover, the previous studies including Global Youth Tobacco Surveillance (GYTS), Nepal have not explored these factors. There is a need of information at multiple levels on the relationship of media exposure and tobacco/cigarette smoking to address the escalating use of tobacco among adolescents.

\section{Methods}

\subsection{Study Design, Setting and Data Collection}

An observational cross-sectional study was done among 394 students studying in the " $10+2$ " colleges of Kathmandu district, Nepal from March to August, 2013. In Nepal, $10+2$ level studies mean higher secondary studies (i.e. grade 11 and grade 12) taught at the college after completion of School Leaving Certificate (SLC) level. Many students from different parts of Nepal, after having passed SLC level prefer going to Kathmandu, the capital city for $10+2$ level studies. In this context, it is imperative to study adolescents' vulnerability to different risky behaviors like cigarette smoking.

Ethical approval for this study was taken from the research evaluation committee of University Grants Commission (UGC), Nepal. For selecting colleges, at first the list of $10+2$ colleges of Kathmandu district under 
Higher Secondary Education Board (HSEB) of Nepal was obtained that yielded a total of 56 colleges. From among 50 colleges that gave consent for study, 3 were randomly selected. In each college, grade 11 and grade 12 students were selected from attendance sheet using Probability Proportionate to Size (PPS) method. Informed consent was taken from the students before administering the questionnaire. The selected students were shared the objective of the study, explained the questionnaire, assured confidentiality of their information and administered the questionnaire individually. During data collection, different measures were taken to ensure students about the anonymity of their information e.g. teachers were not present during information collection, name of students was not taken, and the respondents were asked to fill the questionnaire by themselves.

\subsection{Data Processing and Analysis}

Data was entered and analysed using IBM SPSS 20 for windows. Smoking status of students was divided into current smokers, ever smokers and never smokers. Current smokers included those who have smoked at least 1 stick cigarette in last 30 days from date of interview. Ever smokers included those who have not smoked any in last 30 days but have smoked occasionally or have puffed few times till the date of interview. Similarly, never smokers included those who have never smoked cigarette. To measure the receptivity to cigarette advertisement, variables were derived from the study done by Giplin et al., and were modified to suit in Nepalese context. Receptivity was measured using two variables: "recall at least one cigarette brand name" and "like to wear clothes with cigarette promoting contents or logo" [15]. Those who could both recall a brand of cigarette and like to wear clothes promoting cigarette smoking were categorized as having high receptivity to cigarette advertisement; those who either could recall the brand or liked to wear such clothes were categorized as having moderate receptivity and; those who neither could recall the brand nor like to wear such clothes were categorized as having poor receptivity to cigarette advertisement. Chi-square statistics was used to show the relationship between independent variables and cigarette smoking status which was followed by multinomial logistic regression done to show the association between smoking status and receptivity to cigarette advertisement.

\section{Results}

\subsection{Socio-Demographic Information}

The median age of respondents was 17 years. Sixty seven percent of the respondents were male. Only $34 \%$ of the respondents had family members who smoked cigarette and $37.9 \%$ had at least one family member drinking alcohol. Seventeen percent of the respondents were current smokers. The median age at first smoking was 15 years. Table 1 shows that, socio-demographic variables like sex, perceived educational status, pocket money available to respondents, use of other tobacco products and; smoking and alcohol use by the family members were statistically significant with the smoking status of the respondents at 99\% CI (p-value $<0.01$ ).

\subsection{Smoking and Media}

\section{Media Exposure and Cigarette Smoking}

Around $22 \%$ of respondents saw cigarette advertisement frequently, $24.8 \%$ attended musical programs and $27.7 \%$ saw games sponsored by cigarette companies. Football (55.5\%), cricket (23.1\%) and golf (16.6\%) were among major games as sponsored by cigarette companies seen by respondents. According to most of the respondents, this type of sponsorship are done to promote the cigarette consumption and they succeed in doing so by creating interest and enthusiasm among adolescents about what cigarette is and how it tastes. Around $21 \%$ of respondents mostly watched movies in cinema halls and around $17 \%$ liked to smoke if favourite artist smokes. One fourth of respondents watched television for more than 2 hours a day and around 14\% of respondents were highly receptive to cigarette advertisement. Table 2 shows the relationship between media exposure and cigarette smoking. Independent variables that were found statistically significant with cigarette smoking status at $99 \% \mathrm{CI}(\mathrm{p}<0.01)$ were: attend musical program sponsored by cigarette companies, watch movie in cinema hall, like to smoke if favourite artist smokes, time spent a day in watching TV, liking heavy metal or hard rock music and receptivity to cigarette advertisement.

Table 3 shows multinomial logistic regression analysis between receptivity to cigarette advertisement and cigarette smoking status after adjusting for sex and use of other tobacco products. It was found that, those who are highly receptive to advertisement were more likely to be current smoker (OR $=71.416$, CI: 8.796 - 579.823) 
Table 1. Socio-demographic characteristics and smoking behavior.

\begin{tabular}{|c|c|c|c|c|c|}
\hline \multirow{2}{*}{ Socio-demographic characteristics } & \multicolumn{3}{|c|}{ Smoking status } & \multirow{2}{*}{$\begin{array}{l}\text { Total } \\
\text { (\% of } n)\end{array}$} & \multirow{2}{*}{$\begin{array}{l}\text { Unadjusted } \\
\text { p-value }\end{array}$} \\
\hline & Current smoker & Ever smoker & Never smoker & & \\
\hline Sex $(n=394)$ & & & & & 0.000 \\
\hline Male & $59(22.4)$ & $15(5.7)$ & 189 (71.9) & $263(66.8)$ & \\
\hline Female & $8(6.1)$ & $6(4.6)$ & $117(89.3)$ & $131(33.2)$ & \\
\hline Perceived educational status $(\mathrm{n}=394)$ & & & & & 0.000 \\
\hline Good & $26(10.4)$ & $13(5.2)$ & $211(84.4)$ & $250(63.4)$ & \\
\hline Satisfactory & $37(27.4)$ & $7(5.2)$ & $91(67.4)$ & $135(34.3)$ & \\
\hline Poor & $4(44.4)$ & $1(11.1)$ & $4(44.4)$ & $9(2.3)$ & \\
\hline Pocket money (per month) $(\mathrm{n}=336)$ & & & & & 0.000 \\
\hline NRs 2500 or less & $24(11.9)$ & $6(3)$ & $172(85.1)$ & $202(60.1)$ & \\
\hline NRs 2500 - 5000 & $26(25.2)$ & $11(10.7)$ & $66(64.1)$ & $103(30.7)$ & \\
\hline More than NRs 5000 & $13(41.9)$ & $1(3.2)$ & $17(54.8)$ & $31(9.2)$ & \\
\hline Use of other tobacco products $(n=386)$ & & & & & 0.000 \\
\hline Yes & $26(57.8)$ & $6(13.3)$ & $13(28.9)$ & 45 (11.7) & \\
\hline No & $41(12)$ & $15(4.4)$ & $285(83.6)$ & $341(88.3)$ & \\
\hline Smoking by family member $(n=394)$ & & & & & 0.000 \\
\hline Yes & $39(29.1)$ & $7(5.2)$ & $88(65.7)$ & $134(34)$ & \\
\hline No & $28(10.8)$ & $14(5.4)$ & $218(83.8)$ & $260(66)$ & \\
\hline Alcohol use by family members $(\mathrm{n}=382)$ & & & & & 0.000 \\
\hline Yes & $44(30.3)$ & $10(6.9)$ & $91(62.8)$ & $145(38)$ & \\
\hline No & $22(9.3)$ & $11(4.6)$ & $204(86.1)$ & $237(62)$ & \\
\hline
\end{tabular}

Note: Values in parenthesis under smoking status indicate percentage of row total.

and ever smokers (OR = 9.582, CI: 2.201 - 41.714) compared to never smokers.

\subsection{Views on Role of Media}

Views like "media teaches different ways of smoking to its audiences", "media uses different models to teach smoking to adolescents" and "media promotes discussion among about smoking among adolescents" were agreed by $78.6 \%, 70.1 \%$ and $64.1 \%$ of the respondents respectively. One third of the respondents (35.7\%) agreed that media shows social importance of smoking (Table 4).

\section{Discussion}

There are separate roles for entertainment media and tobacco marketing on adolescents' smoking [16]. DuRant et al. [17] examined the content of tobacco and alcohol use behaviors on television and found out that a high percentage (26\%) of MTV videos portrayed tobacco use. The same study found that, given the influence of modeling and imitation in young people, videos that portrayed alcohol and tobacco use depicted the lead performer as most often the one observed to be smoking or drinking. A study done in 2010 in India [18] showed that smoking was more common among men who watched television daily compared to those who never watched television and among those who attended the cinema monthly compared to those who did not. Similar finding was obtained from this study where significant association $(\mathrm{p}<0.01)$ was found between time of watching television in a day and smoking behavior. Frequently watching movies in cinema halls and watching television for more hours indirectly expose adolescents in smoking promoting contents that shape their attitudes and 
Table 2. Media related variables and smoking habit.

\begin{tabular}{|c|c|c|c|c|c|}
\hline \multirow{2}{*}{ Media related variables } & \multicolumn{3}{|c|}{ Cigarette smoking status } & \multirow{2}{*}{$\begin{array}{l}\text { Total } \\
\text { (\% of n) }\end{array}$} & \multirow{2}{*}{$\begin{array}{l}\text { Unadjusted } \\
\text { p-value }\end{array}$} \\
\hline & Current smoker & Ever smoker & Never smoker & & \\
\hline See advertisement of cigarette $(n=384)$ & & & & & $0.026^{*}$ \\
\hline Yes, frequently & 21 & 6 & 59 & $86(22.4)$ & \\
\hline Yes, sometimes & 39 & 14 & 173 & $226(58.8)$ & \\
\hline No & 6 & 1 & 65 & $72(18.8)$ & \\
\hline Read fashion magazine $(\mathrm{n}=391)$ & & & & & $0.023^{*}$ \\
\hline Yes & 53 & 13 & 186 & $252(64.4)$ & \\
\hline No & 14 & 8 & 117 & 139 (35.6) & \\
\hline $\begin{array}{l}\text { Attended musical program sponsored by } \\
\text { cigarette company }(\mathrm{n}=326)\end{array}$ & & & & & $0.005^{* *}$ \\
\hline Yes & 23 & 7 & 51 & $81(24.8)$ & \\
\hline No & 36 & 11 & 198 & $245(75.2)$ & \\
\hline $\begin{array}{l}\text { Seen games sponsored by cigarette companies } \\
(\mathrm{n}=383)\end{array}$ & & & & & 0.403 \\
\hline Yes & 23 & 5 & 78 & $106(27.7)$ & \\
\hline No & 44 & 13 & 220 & $277(72.3)$ & \\
\hline Watch movie in cinema hall $(\mathrm{n}=393)$ & & & & & $0.000^{* *}$ \\
\hline Mostly & 26 & 6 & 50 & $82(20.9)$ & \\
\hline Sometimes & 27 & 13 & 121 & $161(41)$ & \\
\hline Rarely & 10 & 2 & 106 & $118(30)$ & \\
\hline Never & 4 & 0 & 28 & $32(8.1)$ & \\
\hline $\begin{array}{l}\text { Like to smoke if favorite artist is smoking? } \\
(\mathrm{n}=390)\end{array}$ & & & & & $0.000^{* *}$ \\
\hline Yes & 31 & 8 & 27 & $66(16.9)$ & \\
\hline No & 34 & 13 & 277 & $324(83.1)$ & \\
\hline Time spent in viewing TV in a day $(\mathrm{n}=376)$ & & & & & $0.001^{* *}$ \\
\hline 0 - 2 hours & 42 & 11 & 230 & $283(75.3)$ & \\
\hline 2 - 4 hours & 14 & 6 & 51 & 71 (18.9) & \\
\hline $4-6$ hours & 5 & 2 & 6 & $13(3.4)$ & \\
\hline More than 6 hours & 4 & 2 & 3 & $9(2.4)$ & \\
\hline Like heavy metal or hard rock music $(\mathrm{n}=390)$ & & & & & $0.000^{* *}$ \\
\hline Yes, always & 39 & 8 & 64 & $111(28.4)$ & \\
\hline Yes, sometimes & 17 & 9 & 156 & $182(46.7)$ & \\
\hline No & 10 & 4 & 83 & $97(24.9)$ & \\
\hline Receptivity to cigarette advertisement $(\mathrm{n}=383$ ) & & & & & $0.000^{* *}$ \\
\hline High & 26 & 8 & 18 & $52(13.6)$ & \\
\hline Moderate & 40 & 10 & 185 & $235(61.3)$ & \\
\hline Poor & 1 & 3 & 92 & $96(25.1)$ & \\
\hline
\end{tabular}

${ }^{*} \mathrm{p}<0.05,{ }^{* *} \mathrm{p}<0.01$. 
Table 3. Smoking status of respondents by receptivity to cigarette advertisement, adjusted for sex and other forms of tobacco use: multinomial logistic regression analysis $(n=394)$.

\begin{tabular}{|c|c|c|c|c|}
\hline \multirow{3}{*}{$\begin{array}{c}\text { Variable } \\
\text { Receptivity to cigarette advertisement }\end{array}$} & \multicolumn{4}{|c|}{ Reference group = never smokers } \\
\hline & \multicolumn{2}{|c|}{ Current smoker } & \multicolumn{2}{|c|}{ Ever smoker } \\
\hline & OR & $95 \% \mathrm{CI}$ & OR & $95 \% \mathrm{CI}$ \\
\hline High & $71.416^{*}$ & $8.796-579.823$ & $9.582^{*}$ & $2.201-41.710$ \\
\hline Moderate & $18.505^{*}$ & $2.454-139.518$ & $1.539^{* *}$ & $0.408-5.805$ \\
\hline
\end{tabular}

Nagelkerke $\mathrm{R}^{2}=0.355,-2$ log-likelihhood $=99.294$, Chi-square $=44.274$; Reference category for independent variable: Poor receptivity to cigarette advertisement; Adjusted for: sex (male, female) and use of other forms of tobacco (yes, no); $\mathrm{p}<0.01,{ }^{* * *} \mathrm{p}=0.524$.

Table 4. Views on role of media.

\begin{tabular}{|c|c|c|c|}
\hline Statements & Agree & Can’t say & Disagree \\
\hline Media teaches different ways of smoking to its audience $(n=383)$ & $301(78.6)$ & $24(6.3)$ & $58(15.1)$ \\
\hline Media uses different models to teach smoking to adolescents $(\mathrm{n}=384)$ & $269(70.1)$ & $29(7.6)$ & $86(22.4)$ \\
\hline Media shows social importance of smoking $(n=381)$ & $136(35.7)$ & $43(11.3)$ & $202(53)$ \\
\hline Media promotes discussion among adolescents about smoking and its ways $(n=382)$ & $245(64.1)$ & $37(9.7)$ & $100(26.2)$ \\
\hline
\end{tabular}

Numbers in the parenthesis indicate percentage of row total.

affect their smoking status though the contents might have been targeted for older adults. A study done in 2006 among youths in grades 10 and 12, demonstrated that during the 4 months leading up to survey administration, each additional viewing of a tobacco company parent-targeted advertisement was, on average, associated with lower perceived harm of smoking, stronger approval of smoking, stronger intentions to smoke in the future, and greater likelihood of having smoked in the past 30 days [19].

Results from a study done to examine whether identifying with a smoker film character increases implicit association of the self with smoking provided the evidence that exposure to smoking in movies is causally related to changes in smoking related thoughts, that identification with protagonists is an important feature of narrative influence and implicit measures may predict the deliberate behavior [20]. In India, nearly 38\% of the tobacco incidents in Indian films are filmed with leading actors who are powerful role models for youth to start smoking and perceive smoking as associated with celebration and fun as depicted in the films [21]. A study in Zambia found positive association between youth smoking and seeing actors smoking in media though negative association was found for variables like possessing item with cigarette brand logo and seeing advertisement on billboards [22]. A study done in 2008 showed that after rigorous covariate control, exposure to films and music are associated with smoking [23].

Giplin in 2007 has found that odds of initiating smoking increased by $46 \%$ for youth who were moderately receptive to advertising and by $84 \%$ in youth who were highly receptive to advertising [15]. Similarly, a study done among teenagers and young adults demonstrated strong influence of receptivity to advertising on both susceptibility to smoking, experimenting and regular smoking after adjusting for other important variables like exposure to smoking from friends and family [24]. Strong influence of receptivity to advertising on both current smoking $(\mathrm{OR}=71.416)$ and ever smoking $(\mathrm{OR}=9.582)$ was demonstrated by present study as well. However there is need of information on dose response relationship in order to determine whether the relationship between two variables is causal.

Results after administering the statements that reflects smoking provoking role of media showed that majority of respondents agree upon the view that media promote smoking among adolescents. According to McCool's media interpretation model, attitudes are mediated by exposure to film, which contribute to the perception of smoking prevalence, permissiveness toward smokers and smoking imagery, and enhances smoking intention. Smoking imagery in film may play a role in the development of smoking intentions through inflating the perception of smoking prevalence and presenting socially attractive images [25]. 


\section{Conclusion}

This study is based on the self-reported exposure as well as view of adolescent students towards media and its role on promoting cigarette smoking among individuals of their age. Findings from this study show that different forms of media including cinema, music, magazines, television, games and music sponsorship are found to be important predictors for smoking status of college students in urban Nepal. Thus both entertainment media and tobacco marketing require equal emphasis from policy standpoint. Formulation of strict policies as well as monitoring the activities of media regarding promotion of harmful behavior including cigarette smoking regularly can be beneficial to lead adolescents towards a healthy life. The study has included adolescent students from Kathmandu, the capital city of Nepal, it represents only students in urban Nepal which is one of its limitations. So, further research on large scale on this area is required for significant policy implication.

\section{Acknowledgements}

We are highly indebted to Dr B. D. Chataut; Principal of CIST College and former Directorate General of Health at Ministry of Health, Nepal for his encouragement throughout the research project. We are heartily thankful to all the colleges that gave permission for study. We acknowledge all the students who participated in the study. We would like to thank the data enumerators: Mr. Madhav KC and Mr. Saurav Chandra Acharya. The authors acknowledge University Grants Commission (UGC), Nepal for providing fund to conduct this study.

\section{Competing Interests}

The authors declare that they have no competing interests.

\section{References}

[1] WHO (2013) Tobacco. http://www.who.int/mediacentre/factsheets/fs339/en/

[2] Kahandaliyanage, A. (2013) Speech Delivered at Regional Meeting on Countering Tobacco Industry Interference, 19-21 March 2013.

[3] Ministry of Health and Population, New ERA, ICF International Inc. (2012) Nepal Demographic and Health Survey 2011. Ministry of Health and Population, New ERA, Kathmandu and ICF International, Calverton, Maryland.

[4] MoHP (2010) Brief Profile on Tobacco Control in Nepal. Government of Nepal, Ministry of Health and Population, Kathmandu.

[5] CBS (2011) Preliminary Report of National Census. Central Bureau of Statistics, Kathmandu.

[6] Braverman, M.T. and Aarø, L.E. (2004) Adolescent Smoking and Exposure to Tobacco Marketing Under a Tobacco Advertising Ban: Findings from 2 Norwegian National Samples. American Journal of Public Health, 94, 1230-1238. http://dx.doi.org/10.2105/AJPH.94.7.1230

[7] Krauth, B. (2007) Peer and Selection Effects on Youth Smoking in California. Journal of Business and Economic Statistics, 25, 288-298. http://dx.doi.org/10.1198/073500106000000396

[8] U.S. Department of Health and Human Services (1994) Preventing Tobacco Use among Young People: A Report of the Surgeon General. USDHHS, Atlanta.

[9] US Food Drug Administration (1995) Regulations Restricting the Sale and Distribution of Cigarettes and Smokeless Tobacco Products to Protect Children and Adolescents. US Department of Health and Human Services, Washington DC.

[10] Lovato, C., Watts, A. and Stead, L.F. (2011) Impact of Tobacco Advertising and Promotion on Increasing Adolescent Smoking Behaviours (Review). The Cochrane Library, No. 10, Article ID: CD003439.

[11] Wakefield, M., Flay, B., Nichter, M. and Giovino, G. (2003) Role of the Media in Influencing Trajectories of Youth Smoking. Addiction, 98, 79-103. http://dx.doi.org/10.1046/j.1360-0443.98.s1.6.x

[12] WHO FCTC (2013) Nepal—New Tobacco Control Bill Approved. http://www.who.int/fctc/implementation/news/nep/en/

[13] Tobacco Control Laws (2012) Country Details for Nepal: Introduction. http://www.tobaccocontrollaws.org/legislation/country/nepal/summary

[14] Tobacco Control Laws (2012) Country Details for Nepal: Regulated Forms of Advertisement, Promotion and Sponsorship. http://www.tobaccocontrollaws.org/legislation/country/nepal/aps-regulated-forms 
[15] Gilpin, E.A., White, M.M., Messer, K. and Pierce, J.P. (2007) Receptivity to Tobacco Advertising and Promotions among Young Adolescents as a Predictor of Established Smoking in Young Adulthood. American Journal of Public Health, 97, 1489-1495. http://dx.doi.org/10.2105/AJPH.2005.070359

[16] Sargent, J.D., Gibson, J. and Heatherton, T.F. (2009) Comparing the Effects of Entertainment Media and Tobacco Marketing on Youth Smoking. Tobacco Control, 18, 47-53. http://dx.doi.org/10.1136/tc.2008.026153

[17] DuRant, R.H., Rome, E.S., Rich, M., Allred, E., Emans, S.J., Woods, E.R., et al. (1997) Tobacco and Alcohol Use Behaviors Portrayed in Music Videos: A Content Analysis. American Journal of Public Health, 87, 1131-1135. http://dx.doi.org/10.2105/AJPH.87.7.1131

[18] Vishownath, K., Ackerson, L.K., Sorensen, G. and Gupta, P.C. (2010) Movies and TV Influence Tobacco Use in India: Findings from a National Survey. PLoS ONE, 5, e11365.

[19] Wakefield, M., Terry-McElrath, Y., Emery, S., Saffer, H., Chaloupka, F.J., Szczypka, G., et al. (2006) Effect of Televised, Tobacco Company-Funded Smoking Prevention Advertising on Youth Smoking-Related Beliefs, Intentions, and Behavior. American Journal of Public Health, 96, 2154-2160. http://dx.doi.org/10.2105/AJPH.2005.083352

[20] Cin, S.D., Gibson, B., Zanna, M.P., Shumate, R. and Fong, G.T. (2007) Smoking in Movies, Implicit Associations of Smoking with the Self, and Intensions to Smoke. Psychological Science, 18, 559-563.

[21] WHO (2003) "Bollywood”: Victim or Ally? A WHO Study on the Portryal of Tobacco in Indian Cinema. Geneva.

[22] Zulu, R., Siziya, S., Muula, A.S. and Rudatsikira, E. (2009) Associations of Advertisement-Promotion-SponsorshipRelated Factors with Current Cigarette Smoking among In-School Adolescents in Zambia. Annals of African Medicine, 8, 229-235. http://dx.doi.org/10.4103/1596-3519.59577

[23] Primack, B.A., Land, S.R. and Fine, M.J. (2008) Adolescent Smoking and Volume of Exposure to Various Forms of Media. Public Health, 122, 379-389. http://dx.doi.org/10.1016/j.puhe.2007.07.022

[24] Kaufman, N.J., Castrucci, B.C., Mowery, P., Gerlach, K.K., Emont, S. and Orleans, C.T. (2004) Changes in Adolescent Cigarette Brand Preference, 1989 to 1996. American Journal of Health Behavior, 28, 54-62. http://dx.doi.org/10.5993/AJHB.28.1.6

[25] McCool, J.P., Cameron, L.D. and Petrie, K.J. (2005) The Influence of Smoking Imagery on the Smoking Intentions of Young People: Testing a Media Interpretation Model. Journal of Adolescent Health, 36, 475-485. http://dx.doi.org/10.1016/j.jadohealth.2004.03.006 
Scientific Research Publishing (SCIRP) is one of the largest Open Access journal publishers. It is currently publishing more than 200 open access, online, peer-reviewed journals covering a wide range of academic disciplines. SCIRP serves the worldwide academic communities and contributes to the progress and application of science with its publication.

Other selected journals from SCIRP are listed as below. Submit your manuscript to us via either submit@scirp.org or Online Submission Portal.
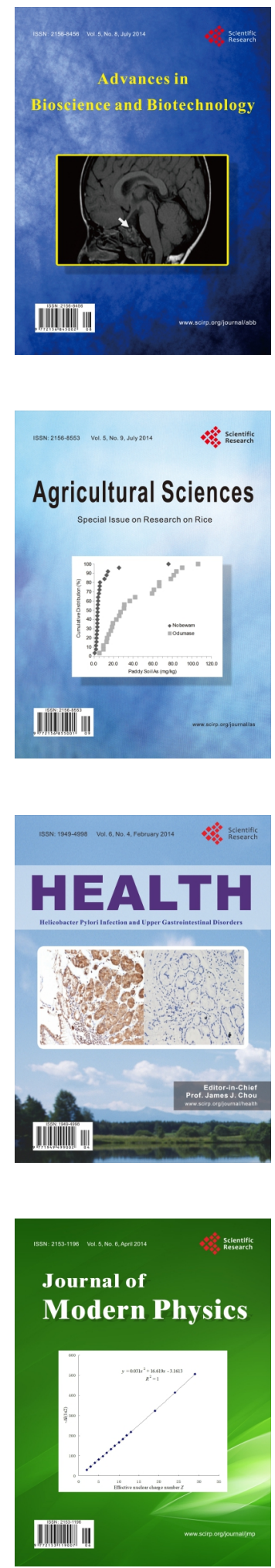
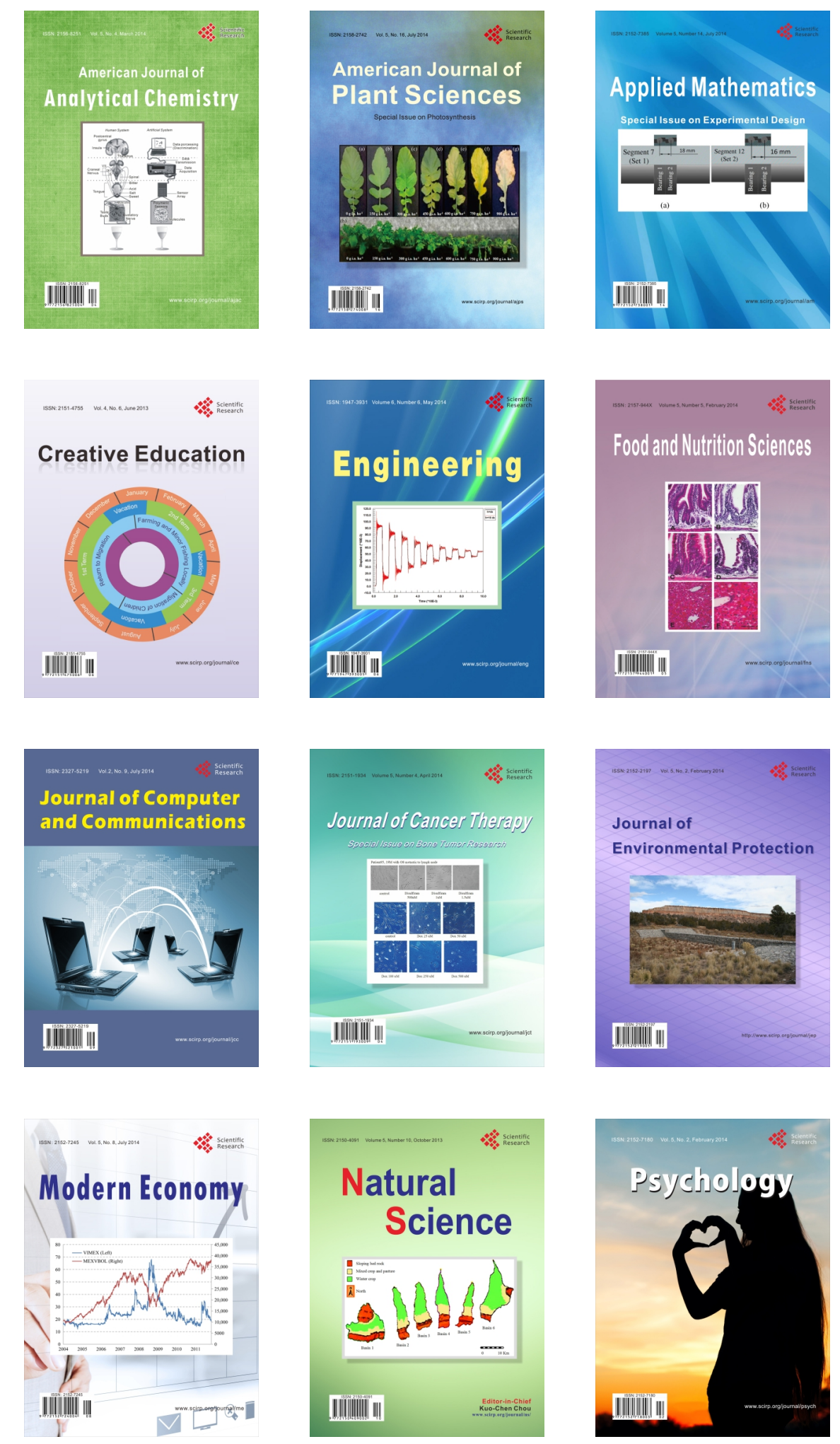